\title{
Immunoconglutinin and Complement Studies in Congenital Nephrotic Syndrome and Nephritis of Henoch-Schönlein Purpura in Children
}

\author{
S. T. SHULMAN, T. M. BARRATT, and J. F. SOOTHILL \\ From the Department of Immunology, Institute of Child Health, London
}

\begin{abstract}
Shulman, S. T., Barratt, T. M., and Soothill, J. F. (1971). Archives of Disease in Childhood, 46, 838. Immunoconglutinin and complement studies in congenital nephrotic syndrome and nephritis of Henoch-Schönlein purpura in children. Evidence of complement activation in 6 children with congenital nephrotic syndrome and 9 children with nephritis associated with Henoch-Schönlein purpura was sought by estimating the concentration and by immunoelectrophoretic analysis of the complement component $\mathrm{C} 3$, and by immunoconglutinin titration (IK: an autoantibody to reacted complement components). IK and quantitative C3 levels did not differ significantly from control values in either disease; in vivo C3 conversion was not detected in plasma from congenital nephrotic patients, but was present in 2 of 9 patients with Henoch-Schönlein nephritis. The data do not provide consistent evidence of complement involvement in either disease.
\end{abstract}

Several renal diseases are believed to have an immune pathogenesis; the evidence includes depression of serum complement and the demonstration of the glomerular deposition of complement components and immunoglobulin by immunofluorescence. However, the congenital nephrotic syndrome and the nephritis associated with HenochSchönlein purpura (HSP) are two diseases in which the role of immunopathogenetic mechanisms is unclear.

The congenital nephrotic syndrome is invariably resistant to therapy and virtually always fatal (Hallman et al., 1970; Kouvalainen, 1963). An immune pathogenesis has been suggested (Lange et al., 1962, 1963; Kouvalainen, 1963), but the evidence is far from secure and the histological and laboratory data suggest considerable heterogeneity.

Some features suggest antigen-antibody complex deposition in Henoch-Schönlein purpura. However, serum C3 levels have consistently been normal (Ayoub and Hoyer, 1969), though mesangial deposits of C3, immunoglobulin, and fibrinogen have been shown by immunofluorescence (Urizar et al., 1968).

\footnotetext{
Received 5 May 1971.

^Present address: Department of Pediatrics, University of Florida College of Medicine, Gainesville, Florida 32601, U.S.A.
}

The presence of circulating electrophoretical altered C3 (Soothill, 1967) or immunoconglutin (IK), an autoantibody to reacted complement components (Coombs, Coombs, and Ingram, 1961), may provide evidence of complement activation even when serum complement levels or immunofluorescence studies are normal, as has been shown in the acute nephritic syndrome (Ngu and Soothill, 1969) and in the steroid-sensitive relapsing nephrotic syndrome of childhood (Ngu, Barratt, and Soothill, 1970). We report such studies in congenital nephrotic syndrome and the nephritis associated with Henoch-Schönlein purpura.

\section{Patients Studied}

Congenital nephrotic syndrome. Six children, from 4 months to 9 years of age, who developed $S$ heavy proteinuria in the first weeks or months of life were studied. Some clinical features of these patients are shown in Table I. At the time of the study, all had heavy proteinuria, hypoalbuminaemia (serum albumin $<2 \cdot 0 \mathrm{~g} / 100 \mathrm{ml}$ ), oedema, hypercholesterolaemia, and microscopical haematuria. The four patients who had been investigated by renal biopsy (Cases, 2, 3, 4, and 5) showed proliferative glomerular changes. All except Case 1 (untreated) were resistant to corticosteroid therapy. 
TABLE I

Congenital Nephrotic Syndrome

\begin{tabular}{|c|c|c|c|c|c|c|c|c|}
\hline $\begin{array}{l}\text { Case } \\
\text { No. }\end{array}$ & $\begin{array}{l}\text { Age at } \\
\text { Onset } \\
\text { (wk) }\end{array}$ & $\begin{array}{l}\text { Affected } \\
\text { Sibs }\end{array}$ & $\begin{array}{l}\text { Age at } \\
\text { Study } \\
(y r)\end{array}$ & $\begin{array}{c}\text { Plasma C3 } \\
\text { (\% reference } \\
\text { serum })\end{array}$ & $\begin{array}{c}\text { C3 } \\
\text { Immuno- } \\
\text { electrophoresis }\end{array}$ & $\begin{array}{c}\text { Serum IgM } \\
\text { (\% reference } \\
\text { serum) }\end{array}$ & $\begin{array}{c}\text { Serum IK } \\
\left(-\log _{2}\right) \text { Separate } \\
\text { Observations }\end{array}$ & IK/IgM* \\
\hline $\begin{array}{l}1 \\
2 \\
3 \\
4 \\
5 \\
6\end{array}$ & $\begin{array}{r}2 \\
2 \\
8 \\
16 \\
12 \\
1\end{array}$ & $\begin{array}{l}\text { No } \\
\text { Yes } \\
\text { Yes } \\
\text { Yes } \\
\text { Yes } \\
\text { Yes }\end{array}$ & $\begin{array}{l}0 \cdot 3 \\
2 \cdot 5 \\
8 \cdot 8 \\
4 \cdot 5 \\
3 \cdot 0 \\
0 \cdot 3\end{array}$ & $\begin{array}{r}92 \\
184 \\
112 \\
160 \\
96 \\
136\end{array}$ & $\begin{array}{c}- \\
\text { - } \\
\text { not done } \\
\text { not done } \\
\text { not done } \\
-\end{array}$ & $\begin{array}{r}154 \\
208 \\
264 \\
184 \\
64 \\
128\end{array}$ & $\begin{array}{l}5,4 \\
3,3,3 \\
3,4 \\
2,3 \\
1,1 \\
1,1,1\end{array}$ & $\begin{array}{r}14 \cdot 7 \\
3 \cdot 8 \\
4 \cdot 3 \\
3 \cdot 1 \\
3 \cdot 1 \\
1 \cdot 6\end{array}$ \\
\hline
\end{tabular}

^Immunoelectrophoretic evidence of $\mathrm{C} 3$ conversion in vivo is recorded if present as + and if absent as - . Individual estimates of IK are given and presented as the negative logarithm (base 2) of the observed titre. To calculate the IK/IgM ratio, the log mean reciprocal IK titre has been divided by the serum $\operatorname{IgM}\left(\%\right.$ reference serum) and multiplied by $10^{2}$.

TABLE II

Henoch-Schönlein Nephritis

\begin{tabular}{|c|c|c|c|c|c|c|c|c|c|c|}
\hline $\begin{array}{l}\text { Case } \\
\text { No. }\end{array}$ & $\begin{array}{c}\text { Age } \\
\text { at } \\
\text { Onset } \\
\text { (yr) }\end{array}$ & Rash & Arthritis & $\begin{array}{c}\text { Abdominal } \\
\text { Pain }\end{array}$ & $\begin{array}{c}\text { Age } \\
\text { at } \\
\text { Study } \\
\text { (yr) }\end{array}$ & $\begin{array}{c}\text { Plasma C3 } \\
(\% \\
\text { reference } \\
\text { serum })\end{array}$ & $\begin{array}{c}\text { C3 } \\
\text { Immuno- } \\
\text { electro- } \\
\text { phoresis }\end{array}$ & $\begin{array}{c}\text { Serum IgM } \\
(\% \\
\text { reference } \\
\text { serum })\end{array}$ & $\begin{array}{c}\text { Serum IK } \\
\left(-\log _{2}\right) \\
\text { Separate } \\
\text { Estimations }\end{array}$ & IK/IgM* \\
\hline $\begin{array}{r}7 \\
8 \\
9 \\
10 \\
11 \\
12 \\
13 \\
14 \\
15\end{array}$ & $\begin{array}{r}5 \cdot 4 \\
7 \cdot 0 \\
3 \cdot 0 \\
7 \cdot 5 \\
13 \cdot 9 \\
5 \cdot 8 \\
8 \cdot 0 \\
5 \cdot 0 \\
8 \cdot 9\end{array}$ & $\begin{array}{l}+ \\
+ \\
+ \\
+ \\
- \\
+ \\
+ \\
+ \\
+\end{array}$ & $\begin{array}{l}+ \\
+ \\
+ \\
+ \\
+ \\
+ \\
+ \\
+\end{array}$ & $\begin{array}{l}+ \\
+ \\
- \\
+ \\
+ \\
- \\
+ \\
+ \\
-\end{array}$ & $\begin{array}{r}5 \cdot 6 \\
7 \cdot 2 \\
13 \cdot 4 \\
7 \cdot 7 \\
14 \cdot 5 \\
7 \cdot 0 \\
8 \cdot 3 \\
6 \cdot 7 \\
9 \cdot 7\end{array}$ & $\begin{array}{r}92 \\
148 \\
100 \\
200 \\
144 \\
120 \\
176 \\
176 \\
176\end{array}$ & $\begin{array}{l}- \\
+ \\
\overline{+} \\
- \\
- \\
- \\
-\end{array}$ & $\begin{array}{r}104 \\
164 \\
40 \\
128 \\
184 \\
308 \\
48 \\
104 \\
20\end{array}$ & $\begin{array}{c}1,3,2,3 \\
<1,2,2 \\
<1,<1,<1 \\
1,3,2 \\
1,3,3 \\
3,3,3 \\
<1,1,2 \\
2,2 \\
<1,<1\end{array}$ & $\begin{array}{r}4 \cdot 5 \\
1.5 \\
<5 \cdot 0 \\
3 \cdot 1 \\
2 \cdot 7 \\
2 \cdot 6 \\
4 \cdot 2 \\
3 \cdot 8 \\
<10 \cdot 0\end{array}$ \\
\hline
\end{tabular}

^See footnote to Table I.

Henoch-Schönlein purpura. Nine children ranging from 5 to 14 years of age, were considered to have active Henoch-Schönlein nephritis on the basis of persistent haematuria and proteinuria at the time of investigation, 2 months to 5 years after one or more episodes of typical rash, usually with arthritis and abdominal pain. Clinical features are summarized in Table II. Renal biopsy was performed on Cases 7, 8, 9, 11 14, and 15; all showed proliferative changes. Two patients (Cases 9 and 15) had been treated with cyclophosphamide, and Case 15 was on a maintenance dose of cyclophosphamide at the time of the study.

Healthy children. Seventeen apparently healthy schoolchildren aged 9 to 13 years were studied (Table III).

\section{Methods}

The immunoelectrophoretic study of $\mathrm{C} 3$ was performed on EDTA plasma within three hours of collection as described by Soothill (1967). Control plasma from healthy subjects was included in every run. The presence of a single precipitin arc is recorded as negative, and of more than one arc, indicating in vivo conversion
TABLE III

Healthy Children

\begin{tabular}{|c|c|c|c|}
\hline $\begin{array}{l}\text { Age } \\
(y r)\end{array}$ & $\begin{array}{c}\operatorname{IgM}(\% \\
\text { reference serum) }\end{array}$ & $\underset{\left(-\log _{2}\right)}{\text { IK }}$ & IK/IgM* \\
\hline $\begin{array}{r}14 \\
11 \\
11 \\
13 \\
13 \\
13 \\
10 \\
12 \\
9 \\
12 \\
14 \\
13 \\
14 \\
9 \\
10 \\
10 \\
13\end{array}$ & $\begin{array}{r}80 \\
172 \\
220 \\
96 \\
180 \\
40 \\
140 \\
128 \\
240 \\
48 \\
276 \\
80 \\
96 \\
140 \\
128 \\
172 \\
252\end{array}$ & $\begin{array}{r}2 \\
2 \\
2 \\
<1 \\
1 \\
1 \\
2 \\
2 \\
2 \\
<1 \\
3 \\
2 \\
2 \\
<1 \\
2 \\
3 \\
3\end{array}$ & $\begin{array}{r}5 \cdot 0 \\
2 \cdot 3 \\
1 \cdot 8 \\
<2 \cdot 1 \\
5 \cdot 0 \\
2 \cdot 9 \\
3 \cdot 1 \\
1 \cdot 7 \\
4 \cdot 2 \\
<2 \cdot 9 \\
5 \cdot 0 \\
4 \cdot 2 \\
1 \cdot 4 \\
<3 \cdot 1 \\
4 \cdot 7 \\
3 \cdot 2 \\
1 \cdot 1\end{array}$ \\
\hline
\end{tabular}

$\star$ See footnote to Table I.

of C3, as positive. Other studies were performed on serum which had been frozen in aliquots at $-4^{\circ} \mathrm{C}$. C3 was estimated as previously described (Ngu and 
Soothill, 1969) and expressed as a percentage of a reference serum; the normal range in children is 54$230 \%$. IgM was estimated by the single gel diffusion method of Mancini, Carbonara, and Heremans (1965) as a percentage of the MRC standard for immunoglobulins $\mathrm{G}, \mathrm{A}$, and $\mathrm{M}$.

IK was determined by method IIb of Coombs et al. (1961) and expressed as the negative logarithm (base 2) of the observed titre, and the mean of all such observations on each individual was used for statistical calculations. Each batch of IK titrations included randomly distributed sera from patients and from the apparently healthy children. Controls included in each batch of IK determinations were a known negative serum, antiC3 antiserum, and a known positive serum. The importance of this experimental design is indicated by the observation of somewhat higher IK titres in the apparently healthy children in this series than in the earlier study of $\mathrm{Ngu}$ and Soothill (1969). IK is a predominantly $\operatorname{IgM}$ antibody and $\operatorname{IgM}$ concentration may be altered non-specifically in the nephrotic syndrome. To correct for this, IK/IgM ratios were calculated by dividing the log mean reciprocal IK titre by the serum IgM (\% reference serum) and multiplying by 100 .

\section{Results}

The results in patients are summarized in Tables I and II, and in healthy children in Table III. No significant differences were observed when the median IK, C3, IgM, or IK/IgM ratios of the congenital nephrotic or of the Henoch-Schönlein groups were compared with those of the control group by the Wilcoxon Rank-sum test $(2 \alpha=0 \cdot 05)$. One patient in each disease group, Case 1 and 15, however, gave values well above those of the control series.

Sera from 2 of the 9 patients with HenochSchönlein nephritis had altered circulating C3 indicated by immunoelectrophoresis, but none of the three congenital nephrotic patients so studied had this phenomenon.

\section{Discussion}

Congenital nephrotic syndrome. The data reveal normal plasma levels of IgM and C.3, absence of the altered immunoelectrophoretic pattern of $\mathrm{C} 3$, and IK titres not significantly raised above control levels; they thus fail to support (but do not exclude) the concept of activation of the complement system in British children with the congenital nephrotic syndrome. However, in one child IK titres exceeded the control values: the condition is probably heterogeneous.

It has been suggested that the congenital nephrotic syndrome may have an immunopathogenetic basis (Lange et al., 1962, 1963; Kouvalainen, 1963), The reported data to support this concept are: (a) consistently depressed total haemolytic complement in one congenital nephrotic patient (Lange et al., 1962); (b) this patient had immunofluorescence evidence of glomerular localization of $\mathrm{C} 3, \mathrm{C} 1$, and immunoglobulin on renal biopsy (Lange et al., 1962), and Kouvalainen (1963) found glomerular capillary wall immunoglobulin deposits in all 6 children with congenital nephrotic syndrome; (c) using a semiquantitative technique, Kouvalainen (1963) found markedly raised $\mathrm{IgM}$ levels in sera from congenital nephrotic patients, both in cord samples and in patients up to 24 months old; 6 of 10 mothers of such patients also had high serum IgM levels; (d) Kouvalainen et al. (1962) also reported a high incidence of antibodies precipitating in gel with kidney, placenta, and liver extracts in both congenital nephrotic patients and in their mothers; and (e) observed accelerated rejection of grafts of skin from congenital nephrotic patients by their mothers when compared to the maternal rejection of grafts from older normal sibs.

It is likely that the congenital nephrotic syndrome is not a homogeneous disease. The heterogeneity of the histological findings lends support to this concept. The congenital nephrotic syndrome seen in Finland, characterized by an autosomal recessive mode of inheritance (Norio, 1966), an intrauterine onset of the disease (Kouvalainen, 1963), consistent pathological findings of proxima tubule dilatation (Paatela, 1963) and proliferative glomerular changes (Hjelt and Hallman, 1958), may not be related to the varieties seen in other countries. Other interpretations are possible for Kouvalainen's findings than the immunopathogenetic ones originally proposed by him, and the Finnish experience may not reflect that of the rest of the world. The only indication of complement activation we observed in our six patients was the high value for IK in Case 1. This could result from the heterogeneity of the group, or from a coincidental antigen stimulus.

Henoch-Schönlein nephritis. The aetiology of Henoch-Schönlein purpura is unknown, though certain parallels with immune complex disease and with intravascular coagulopathies have been noted (Urizar et al., 1968). Serum haemolytic complement and C3 determinations have uniformly been normal (Ayoub and Hoyer, 1969; West, Northway, and Davis, 1964; Gotoff et al., 1965; Wedgwood and Janeway, 1953; Urizar et al., 1968), and our results in 9 patients were consistent with this. Immunofluorescence studies of renal biopsies have shown variable mesangial deposits of IgG, C3, and fibrin (Drummond and Michael, 
1966; Ayoub and Hoyer, 1969; Urizar et al., 1968) though some cases have been reported without such deposits (Goldbloom and Drummond, 1968). Dermal biopsies reveal perivascular IgG, C3, and fibrin deposits (Drummond and Michael, 1966).

Our studies were also variable, in that though IK values were not significantly different from the control series; 2 of the 9 patients had reacted C3 in their serum on immunoelectrophoresis. This phenomenon is not constant in progressive glomerulonephritis (Soothill, 1967) and its presence presumably may vary with the activity of the disease. The low level of IgM found in one patient (Case 15) has not been previously reported; it was not found in our other patients, and the median $\operatorname{IgM}$ level did not differ significantly from the controls.

These studies, though providing new data relevant to the possible immunopathogenesis of these two diseases, are inconclusive. Significant differences from a control series provide strong support for this, but negative or inconsistent results are inconclusive.

We are grateful to Drs. B. C. Macnamara, L. F. Jones, D. Morris, G. Katz and to the paediatricians of The Hospital for Sick Children, for allowing us to study their patients.

\section{REFERENCES}

Ayoub, E. M., and Hoyer, J. (1969). Anaphylactoid purpura:

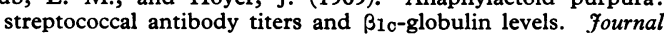
of Pediatrics, 75, 193.

Coombs, R. R. A., Coombs, A. M., and Ingram, D. G. (1961). The Serology of Conglutination. Blackwell, Oxford.

Drummond, K. N., and Michael, A. F. (1966). Immunopathologic studies of the cutaneous and renal manifestations of anaphylactoid purpura. (Abst.) fournal of Pediatrics, 69, 981.

Goldbloom, R. B., and Drummond, K. N. (1968). Anaphylactoid purpura with massive gastrointestinal hemorrhage and glomerulonephritis. American fournal of Diseases of Children, 116, 97.

Gotoff, S. P., Fellers, F. X., Vawter, G. F., Janeway, C. A., and Rosen, F. S. (1965). The betalc-globulin in childhood nephrotic syndrome: laboratory diagnosis of progressive glomerulonephritis. New England fournal of Medicine, 273, 524.

Hallman, N., Norio, R., Kouvalainen, K., Vilska, J., and Kofo, N. (1970). Das kongenitale nephrotische Syndrom. Ergebnisse der inneren Medizin und Kinderheilkunde, 30, 3.

Hjelt, L., and Hallman, N. (1958). Das Nephrosensyndrom bei Neugeborenen. Monatsschrift für Kinderheilkunde, 106, 190.

Kouvalainen, K. (1963). Immunological features in the congenital nephrotic syndrome: a clinical and experimental study. Annales Paediatriae Fenniae, 9, Suppl 22.

Kouvalainen, K., Vainio, T., Hjelt, L., and Hallman, N. (1962). Behaviour of skin grafted from infant to mother in congenital nephrosis families. Annales Paediatriae Fenniae, 8, 173.

Lange, K., Wachstein, M., Wasserman, E., Alptekin, F., and Slobody, L. B. (1962). Nephrotic syndrome in the newborn infant: an immune reaction? (Abst.) American fournal of Diseases of Children, 104, 496.

Lange, K., Wachstein, M., Wasserman, E., Alptekin, F., and Slobody, L. B. (1963). The congenital nephrotic syndrome. An immune reaction? American fournal of Diseases of Children, 105, 338.

Mancini, G., Carbonara, A. O., and Heremans, J. F. (1965). Immunochemical quantitation of antigens by single radial immunodiffusion. Immunochemistry, 2, 235.

Ngu, J. L., Barratt, T. M., and Soothill, J. F. (1970). Immunoconglutinin and complement changes in steroid sensitive relapsing nephrotic syndrome of children. Clinical and Experimental Immunology, 6, 109.

Ngu, J. L., and Soothill, J. F. (1969). Immunoconglutinin and complement changes in children with acute nephritis. Clinical and Experimental Immunology, 5, 557

Norio, R. (1966). Heredity in the congenital nephrotic syndrome. Annales Paediatriae Fenniae, 12, Suppl. 27.

Paatela, M. (1963). Renal microdissection in infants with special reference to the congenital nephrotic syndrome. Annales Paediatriae Fenniae, 9, Suppl. 21.

Soothill, J. F. (1967). Altered complement component $\mathrm{C}_{3 \mathrm{~A}}\left(\beta_{10}\right.$ $\left.\beta_{1 \mathrm{~A}}\right)$ in patients with glomerulonephritis. Clinical and Experimental Immunology, 2, 83.

Urizar, R. E., Michael, A., Sisson, S., and Vernier, R. L. (1968). Anaphylactoid purpura. II. Immunofluorescent and electron microscopic studies of the glomerular lesions. Laboratory Investigation, 19, 437.

Wedgwood, R. J. P., and Janeway, C. A. (1953). Serum complement in children with 'collagen diseases'. Pediatrics, 11, 569.

West, C. D., Northway, J. D., and Davis, N. C. (1964). Serum levels of betalc-globulin, a complement component, in the nephritides, lipoid nephrosis, and other conditions. Fournal of Clinical Investigation, 43, 1507.

Correspondence to Dr. T. M. Barratt, Department of Immunology, Institute of Child Health, 30 Guilford Street, London W.C.1. 